\title{
Title: Seroprevalence and Risk Factors of SARS CoV-2 in Health Care Workers of Tertiary-Care Hospitals in the Province of Khyber Pakhtunkhwa, Pakistan
}

Authors: Mohsina Haq ${ }^{1}$, Asif Rehman², Muhammad Noor ${ }^{3}$, Jawad Ahmad ${ }^{4}$, Junaid Ahmad ${ }^{5}$, Muhammad Irfan ${ }^{6}$, Saeed Anwar ${ }^{7}$, Sajjad Ahmad $^{8}$, Said Amin ${ }^{10}$, Fawad Rahim ${ }^{9}$, Najib Ul Haq ${ }^{11}$

\section{Academic Degree and Affiliation:}

1. MPhil Microbiology, Assistant Professor Microbiology, Peshawar Medical College, Riphah International University, Islamabad

2. MSc Public Health, Assistant Professor Community Health Sciences, Peshawar Medical College, Riphah International University, Islamabad

3. FCPS, Professor of Medicine, Khyber Girls Medical College, Khyber Medical University, Peshawar.

4. PhD, Professor of Microbiology, Institute of Basic Medical Sciences, Khyber Medical University, Peshawar

5. PhD, Assistant Professor, Prime Institute of Public Health, Riphah International University, Islamabad

6. PhD, Professor of Psychiatry, Peshawar Medical College, Riphah International University, Islamabad

7. MPH, Professor Community Health Sciences, Peshawar Medical College, Riphah International University, Islamabad

8. PhD, Professor of Pathology, Peshawar Medical College, Riphah International University, Islamabad

9. FCPS, Associate Professor of Medicine, Khyber Girls Medical College, Khyber Medical University, Peshawar.

10. FCPS, Assistant Professor of Medicine, Khyber Girls Medical College, Khyber Medical University, Peshawar.

11. MRCP, Professor of Medicine, Peshawar Medical College, Riphah International University, Islamabad

\section{Corresponding Author:}

Dr. NajibUlHaq(MRCP, FCPS, MBBS)

Professor of Medicine, Peshawar Medical College, Warsak Road Peshawar

Email: professornajib@yahoo.com

Contact: 00923219138128 


\begin{abstract}
Background: High number of SARS-CoV-2 infected patients has overburdened healthcare delivery system, particularly in low-income countries. In the recent past many studies from the developed countries have been published on the prevalence of SARS CoV-2 antibodies and the risk factors of COVID-19 in healthcare-workers but little is known from developing countries.
\end{abstract}

Methods: This cross-sectional study was conducted on prevalence of SARS-CoV-2 antibody and risk factors for seropositivity in HCWs in tertiary-care hospitals of Peshawar city, Khyber Pakhtunkhwa province Pakistan.

Results: The overall seroprevalence of SARS CoV-2 antibodies was 30·7\% (CI, 27·8-33.6) in 1011 HCWs. Laboratory technicians had the highest seropositivity $(50 \cdot 0 \%, \mathrm{CI}, 31 \cdot 8-68 \cdot 1)$.

Risk analysis revealed that wearing face-mask and observing social-distancing within a family could reduce the risk $(\mathrm{OR}: 0 \cdot 67 . \mathrm{p}<0 \cdot 05)$ and $(\mathrm{OR}: 0 \cdot 73 . \mathrm{p}<0 \cdot 05)$ while the odds of seropositivity were higher among those attending funeral and visiting local-markets $(\mathrm{OR}: 1 \cdot 83 . \mathrm{p}<0 \cdot 05)$ and $(\mathrm{OR}: 1 \cdot 66 . \mathrm{p}<0 \cdot 01)$. In Univariable analysis, being a nursing staff and a paramedical staff led to higher risk of seropositivity (OR:1.58. p<0.05), (OR:1·79. $\mathrm{p}<0 \cdot 05)$. Fever (OR:2·36, CI, 1·52$3 \cdot 68)$ and loss of smell (OR:2.95, CI: 1·46-5.98) were significantly associated with increased risk of seropositivity $(\mathrm{p}<0.01)$. Among the seropositive HCWs, $165(53 \cdot 2 \%)$ had no symptoms at all while $145(46 \cdot 8 \%)$ had one or more symptoms.

Conclusion: The high prevalence of SARS-CoV-2 antibodies in HCWs warrants for better training and use of protective measure to reduce their risk. Early detection of asymptomatic HCWs may be of special importance because they are likely to be potential threat to others during the active phase of viremia.

Keywords: Seroprevalence, SARS CoV-2, Antibody, Risk Factors, Healthcare Workers. 


\section{Introduction:}

The first case of Corona Virus was reported in BMJ in $1965^{1}$ Many corona viruses have been recovered from animals or humans, however, only two of them have gained attention in the past two decades..$^{2,3,4}$ The transmission of virus to others is typically like that of the "common cold". Healthcare workers are exposed to and at higher risk of acquiring infection while dealing with patients suffering from highly infectious diseases like COVID-19. PCR may be negative even in acute phase in certain cases. ${ }^{5}$ Antibodies tests (anti SARS-CoV-2 antibodies) may be useful in diagnosing PCR negative cases and also provide information about past infection ${ }^{5,6} \mathrm{~A}$ Cochrane review of 54 studies on antibody testing reported that $94 \%$ patients may be positive after the third week of onset of symptoms ${ }^{7}$ and hence may be a better index of past exposure to SARS CoV-2. The role of antibodies in preventing further infection from COVIC-19 is still not clear ${ }^{8}$ however it is assumed that antibodies may provide some protection. ${ }^{9}$

Many studies have been published on the prevalence of SARS CoV-2 antibodies in healthcare workers from developed countries in recent past, however little is known from developing countries. To our knowledge this is the first study of assessing SARS-CoV-2 antibodies of HCWs form both public and private tertiary care hospitals in Peshawar, Pakistan. The present study aims to estimate the seroprevalence of SARS-CoV-2 in HCWEs and explores the possible risk factors of exposure to SARS-CoV-2.

\section{Methods:}

\section{Study design and participants:}

This is a cross-sectional study, following the STROBE (Strengthening the Reporting of Observational Studies in Epidemiology) reporting guidelines, conducted from June 15 to 29, 2020 using purposive sampling technique. The number of HCWs included in the study was 1011. to participate, were included in the study. The HCWS included doctors, paramedics, nurses, medical technicians, laboratory and other staff of the hospitals.

\section{Data Collection procedure:}

The study was approved by Institutional Review Board of Prime Foundation Pakistan. Data about detailed history of risk factors, co-morbid factors, demographic information and symptoms was collected on a semi-structured proforma. Five ml peripheral venous blood was collected in Li 
Heparinised tube, after informed, serum separated using $2500 \mathrm{rpm}$ centrifuge and stored in labelled serum cup for analysis using 20 micro litre serum volume while remaining serum was stored at $80 \mathrm{C}^{0}$ temperature. COBAS e411 system was used for Immunoassay.

\section{Detection of SARS CoV-2 antibodies:}

The FDA approved kit was used for detection of Anti-SARS-CoV-2 antibodies which has high specificity (100\% and sensitivity (more than 98.8\%) according to the manufacturers. ${ }^{10}$, however Public Health England estimated its specificity to be $100 \%$ but a sensitivity of $87 \% .{ }^{11}$ Results were interpreted against a cut off value of $1 \mathrm{AU} / \mathrm{ml}$ and less than $1 \mathrm{AU} / \mathrm{ml}$ was considered Negative and more than or equal to $1 \mathrm{AU} / \mathrm{ml}$ as positive.

\section{Statistical Analysis:}

Statistical analyses were performed using SPSS v.24·0. The means and standard deviations were used to present the continuous variables and the categorical variables were described as the counts and the percentages. Variables with $p$ values $<0 \cdot 01$ in the univariate analysis were further used for a multivariate logistic regression analysis and $p$ value $\leq 0.05$ was considered significant.

\section{Results:}

Socio-demographic characteristics:

The demographic characteristics of healthcare workers are summarized in table 1 below. The FCWS included $688(68 \cdot 1 \%)$ males and $323(31 \cdot 9 \%)$ female. The mean age was 33.6 years (SD $\pm 10 \cdot 5)$ while $454(45 \cdot 0 \%)$ were in the age group 20-29 years and $312(31.0 \%) 30-39$ years. and only $34(3 \cdot 40 \%)$ in age group 60 years and above.

The professional categories of HCWs were, nursing staff $(26 \cdot 1 \%)$, paramedical staff $(21 \cdot 3 \%)$, trainee doctors / medical officers $(11 \cdot 6 \%)$, ward staffs $(11 \cdot 3 \%)$, consultants $(9 \%)$, house officers (6.8\%), Lab Technicians $5 \cdot 2 \%$ and $8 \cdot 7 \%$ were ward support staff members.

Seroprevalence of antibodies against SARS CoV-2:

The overall seroprevalence of SARS-CoV-2 antibodies was 30·7\% (CI 95\%: 27·8-33·6). The seroprevalence was not significantly different $(\mathrm{P}>0 \cdot 02)$ in males $31 \cdot 8 \%$ (CI 95\%: $28 \cdot 3-35 \cdot 4)$ than female $28 \cdot 2 \%$ (CI 95\%: $23 \cdot 3$ - 33.4) female subjects [Table: 1 ].

The age wise seroprevalence of SARS-CoV-2 antibodies was 29.5\% (95\% CI 25·7-33.5) in age group 20-29 years, 33·3\%(95\% CI, 28·1 - 39·8) and it increasing with older age until plateauing 
at age group 50-59 35.5\% (95\% CI, 23.7 - 48.6) while it declined in group 60 years and above $(4 \cdot 2 \%, 95 \%$ CI, $0.1-2 \cdot 1)$ [Table $1 \&$ Graph 1 ]

In different professional category, the highest seroprevalence were identified in Lab technicians $(50 \cdot 0 \%, 95 \%$ CI $31 \cdot 8-68 \cdot 1)$ followed by paramedical staff $(42.0 \%, 95 \%$ CI $34.2-50.1)$, ward staff $(39 \cdot 8 \%, 95 \%$ CI $29 \cdot 4-50 \cdot 7)$ and nursing staff $(38 \cdot 8 \%, 95 \%$ CI $32 \cdot 1-45 \cdot 7)$. while consultant, trainee doctors and house officer had seroprevalence of $(18 \cdot 2 \%, 95 \% \mathrm{CI} 12 \cdot 4-$ $25 \cdot 1),(19 \cdot 9 \%, 95 \%$ CI $14 \cdot 3-26 \cdot 4)$ and $(18 \cdot 4 \%, 95 \%$ CI $11 \cdot 7-26 \cdot 7)$ respectively [Table:1 \& Graph:2].

Among the seropositive HCWs, $165(53 \cdot 2 \%)$ were completely asymptomatic while $145(46 \cdot 8 \%)$ had one or more symptoms. The mean Antibody level was 26·12 (SD $\pm 26 \cdot 79) \mathrm{AU} / \mathrm{ml}$ in seropositive participants (Males 24.63 SD $\pm 25 \cdot 68$, Females 29·72 $\mathrm{SD} \pm 29 \cdot 14$ ). The mean antibody level in seropositive asymptomatic participants was $30 \cdot 20(\mathrm{SD} \pm 29 \cdot 63)$ while in symptomatic it was $21 \cdot 48(\mathrm{SD} \pm 22 \cdot 35)$.

\section{$\underline{\text { Risk Factors }}$}

Gender was not an independent risk factor and the odds of being seropositive were similar between males and females (OR: 1·02, 95\% CI, 0.89-1·41. $\mathrm{p}>0 \cdot 05)$.

The use of face masks and observing social distancing within a family had lesser odds of being seropositive with a statistical significant association (OR: 0.67, 95\% CI, 0.49-0.92. p<0 05), (OR: 0.73, 95\% CI, $0 \cdot 55-1 \cdot 98 . \mathrm{p}<0 \cdot 05)$ in multivariable regression models (MLM) [Table: 2 ]. In MLM, the odds of seropositivity were higher among those attending funeral and visiting local markets for shopping (OR: 1·83, 95\% CI, 1·05 - 3·16. p<0 05) and (OR: $1 \cdot 66,95 \% \mathrm{CI}, 1 \cdot 16-$ 2.37. $\mathrm{p}<0 \cdot 01)$. However the risk of seropositivity did not increase with attending congregational prayers in mosques (OR: 0.52, 95\% CI, 0.34-0.79. $\mathrm{p}<0 \cdot 05)$ [Table: 2].

Seroprevalence in different professional category ranged from $18 \cdot 2 \%(95 \% \mathrm{CI}, 12 \cdot 4-25 \cdot 1)$ in consultants to $50.0 \%(95 \% \mathrm{CI}, 31.8-68.1)$ in laboratory technicians. In Univariable analysis, being a nursing or paramedical staff led to higher risk of seropositivity (OR, 1·58, 95\% CI, 1·15$2 \cdot 17 . \mathrm{p}<0 \cdot 05),(\mathrm{OR}, 1 \cdot 79,95 \% \mathrm{CI}, 1 \cdot 26-2 \cdot 53 . \mathrm{p}<0 \cdot 05)$ but multivariable logistic regression did not show any significant association [Table: 2].

The risk of being seropositivity was strongly ( $\mathrm{p}<0.01)$ associated with fever (OR: $2 \cdot 36,95 \%$ CI: $1 \cdot 52-3 \cdot 68)$ and loss of smell (OR: 2.95, 95\% CI: 1·46-5.98) while loss of taste was strongly associated with seropositivity (OR: $2 \cdot 4,95 \% \mathrm{CI}, 1 \cdot 44-4.00, \mathrm{p}<0 \cdot 001)$ in univariable analysis but 
multivariable logistic regression did not show any significant association. [Table: 2] Co-morbidities were present in $17 \%$ in seropositive subjects and included diabetes $(30 \%)$, hypertension $(36 \cdot 4 \%)$, cardiac disease $(15 \cdot 4 \%)$, asthma $(18 \cdot 2 \%)$ and recent surgery $(40 \%)$.

\section{Discussion:}

To our knowledge this is the first study on prevalence of SARS CoV-2 antibodies in HCW of tertiary care hospitals in Pakistan. Studies form other counties observed lower seroprevalence in HCWs. The seroprevalence of SARS-CoV-2 antibodies in healthcare workers were 30.7\% (CI $95 \%: 27 \cdot 8-33 \cdot 6$ ). It varied from $18.2 \%$ among doctors to $50 \%$ in laboratory technicians. The highest seroprevalence were reported in Lab technicians (50\%) and paramedical staff (42\%) compared to the rest of HCWs. In a study from China, the seroprevalence was $17.14 \%$ while $24 \%$ and $9 \cdot 3 \%$ have been reported from UK and Spain. ${ }^{12,13,14}$ Much lower weighted prevalence (1.07\%) was reported in a Greek study in 1952 HCWs. $^{15}$

The higher seroprevalence of antibodies in our study may indicate higher exposure of HCWs to COVID-19 positive subjects or patients. It may also be due to inadequate use of PPE and education/awareness levels of HCWs. A recent meta-analysis published in the Lancet Journal concluded that physical distancing, use of mask and goggles significantly decrease the risk of infection. ${ }^{16}$ However even in developed countries there have been problems with adequate supplies of PPE and 65\% resident physicians in New York considered it inadequate as reported by the program director. ${ }^{17}$ This warrants for adequate provision of PPE and better training and awareness of HCWs against COVID-19 in HCWs working in tertiary care hospitals in Pakistan.

The risk of seropositivity was significantly high in subject with history of attending funerals (OR:1·83 95\% CI, 1·05-3·16) and visiting local markets (OR: 1·66, 95\% CI, 1·16-2·37) but not in subjects attaining shopping malls. This difference in risk may be due to better observance of preventive protocols, provision of sanitizers at the entrances of shopping malls, where the clients are usually from middle and high income class of the society. In contrast the local markets consist of clusters of small shops providing commodities of common use at cheaper rates. The clients are usually low income group people and there are multiple open accesses of such markets, sanitizers are not provided and social distancing is not observed.

The risk of increased seropositivity was also not associated with attending congregational prayers in mosques (OR:0.52, 95\% CI, 0.34-0.79). This could be possibly due to two main reasons. First, the overall personal and environmental hygienic practices observed as religious obligation in 
It is made available under a CC-BY-NC-ND 4.0 International license .

mosques that includes washing hands and face at least five times a day before prayers and keeping the prayer area clean. Second, voluntary implementation of preventive measures after the consensus decrees on the same by religious scholars. ${ }^{18}$ This also highlights the need of involvement of clergy for effective implementation of public health strategies in conservative societies like Pakistan.

The risk of becoming positive for SARS-CoV-2 antibodies did not increase with history of direct contact with COVID patients within or outside the hospital. This could be due to more careful approach of HCWs when coming in contact with known COVID patients. The same has been reported in other studies that frontline HCWs dealing with COVID patients do not show higher risk of acquiring the infection when compared to Non frontline HCWs. ${ }^{19}$

In our study most of the subjects were asymptomatic. The mean antibodies level in Seropositive asymptomatic participants were significantly higher compared to symptomatic subjects $(p<0 \cdot 001)$. In contrast other studies reported lower antibodies level in asymptomatic patients. ${ }^{20}$ It is also suggested that asymptomatic patients may have lower seroconversion levels but the duration of virus shedding is longer in them when compared to symptomatic patients ${ }^{21}$. The asymptomatic HCWs could therefore be potential threat of transmitting infection.

The large number of asymptomatic HCWs in our study could have been potential source of transmission of infection to their colleagues, hospital staff and contacts outside hospital. This could be one reasons of higher exposure of HCWs to SARS CoV-2 virus and consequently higher seroprevalence in this study. The HCWs need to be more aware of this problem and should preferably have lower threshold of screening themselves with subtle symptoms or even no symptoms. The management of hospitals may offer optional "spot" screening to HCWs. The proposed strategy might pick up otherwise unidentified positive cases for further workup and help in adopting appropriate preventive measures to reduce the transmission of infection.

In multivariate regression analysis two major symptoms i.e. history of fever [OR: $2 \cdot 36,96 \% \mathrm{CI}$, $1 \cdot 52-3 \cdot 68, \mathrm{p}<0 \cdot 001$ ] and loss of smell [OR: 2·95, 95\% CI, 1·46-5.98, p<0.001] were strongly associated with seropositivity. Others symptoms including cough, breathlessness and loss of taste showed a significant correlation in univariate analysis but multivariate analysis did not show a significant association. 
The risk of becoming seropositive was not different significantly in males and females but the mean antibodies titres were significantly high in females $(\mathrm{P}<0.03)$.

Increasing age was a significant risk for SARS-CoV 2 antibodies levels. The highest mean antibody level $(38 \cdot 95 \pm 34 \cdot 88)$ was seen in the age group (50-59) while the lowest $(23 \cdot 73 \pm 25 \cdot 44)$ was in the age group $(20-29)(p=0 \cdot 05)$. In a mathematical model to epidemic data from six countries a positive correlation was found with increasing age and susceptibility of young was almost half to that of adults. ${ }^{22}$

Profession of HCWs was a significant risk and seropositivity with higher prevalence in nursing and paramedical staff compared to consultants and trainee doctors (HOs and MOs/TMOs) in univariate analysis. This is consistent with SARS-CoV study epidemic in $2003 .{ }^{23}$ and could be due to longer duration of contact (more than 30 minutes) ${ }^{14}$ of specific HCWs. However multivariate analysis did not show any significant difference.

The three commonest reported co-morbidities in other studies are hypertension, diabetes and cardiovascular diseases. ${ }^{24}$ In our study the overall co-morbidities were $17 \%$ in seropositive subjects and these were recent history of surgery $40 \%$, hypertension $36 \cdot 4 \%$, diabetes $30 \%$, asthma $18 \cdot 2 \%$ and cardiac disease $15 \cdot 4 \%$.

\section{Conclusions:}

The HCWs in our setup are at high risk of acquiring COVID-19 infection. They need better education on risk factors, training and possibly adequate provision of PPEs to reduce the risk of infection. A large number of asymptomatic HCWS could be potential threat of transmitting infection to others. The HCWs should have a lower threshold for screening of COVID-19 to pick up positive cases and reduce the potential risk to others. SARS Co V 2 antibodies positive HCWs may be considered for voluntary deployment in COVID caring hospitals as they may be at lower risk of acquiring COVID infection. The clergy should be involved in effective implementation of public health strategies in conservative societies like Pakistan. 
medRxiv preprint doi: https://doi.org/10.1101/2020.09.29.20203125; this version posted September 30, 2020. The copyright holder for this preprint (which was not certified by peer review) is the author/funder, who has granted medRxiv a license to display the preprint in perpetuity.

It is made available under a CC-BY-NC-ND 4.0 International license .

Table 1: Sociodemographic Characteristics

\begin{tabular}{|c|c|c|c|c|}
\hline & $\begin{array}{c}\text { Number of } \\
\text { participants } \\
N\end{array}$ & $\begin{array}{c}\text { Seropositive } \\
\text { N(\%) }\end{array}$ & $\begin{array}{c}\text { Seronegative } \\
N(\%)\end{array}$ & $\begin{array}{c}\text { Seroprevalence (95\% CI) } \\
\text { Binomial Exact }\end{array}$ \\
\hline Overall & 1011 & $310(30 \cdot 7 \%)$ & $701(69 \cdot 3 \%)$ & $30 \cdot 7 \%(27 \cdot 8-33 \cdot 6)$ \\
\hline \multicolumn{5}{|l|}{ Gender } \\
\hline Male & 688 & $219(31 \cdot 8 \%)$ & $469(68 \cdot 2 \%)$ & $31 \cdot 8 \%(28.3-35 \cdot 4)$ \\
\hline Female & 323 & $91(28 \cdot 2 \%)$ & $232(71 \cdot 8 \%)$ & $28 \cdot 2 \%(23.3-33 \cdot 4)$ \\
\hline \multicolumn{5}{|l|}{ Age groups } \\
\hline $20-29$ & 532 & $157(29 \cdot 5 \%)$ & $375(70 \cdot 5 \%)$ & $29 \cdot 5 \%(25 \cdot 7-33 \cdot 5)$ \\
\hline $30-39$ & 266 & $90(33 \cdot 8 \%)$ & $176(66 \cdot 2 \%)$ & $33 \cdot 3 \%(28 \cdot 1-39 \cdot 8)$ \\
\hline $40-59$ & 127 & $40(31 \cdot 5 \%)$ & $87(68 \cdot 5 \%)$ & $31 \cdot 5 \%(23 \cdot 5-40 \cdot 3)$ \\
\hline $50-59$ & 62 & $22(35 \cdot 5 \%)$ & $40(64 \cdot 5 \%)$ & $35 \cdot 5 \%(23 \cdot 7-48 \cdot 6)$ \\
\hline 60 and above & 24 & $1(4 \cdot 2 \%)$ & $23(95 \cdot 8 \%)$ & $4 \cdot 2 \%(0 \cdot 1-2 \cdot 11)$ \\
\hline \multicolumn{5}{|l|}{$\begin{array}{l}\text { Professional } \\
\text { category }\end{array}$} \\
\hline Consultant & 154 & $28(18 \cdot 2 \%)$ & $126(81 \cdot 8 \%)$ & $18 \cdot 2 \%(12 \cdot 4-25 \cdot 1)$ \\
\hline MO/TMO & 181 & $36(19 \cdot 9 \%)$ & $145(80 \cdot 1 \%)$ & $19 \cdot 9 \%(14 \cdot 3-26 \cdot 4)$ \\
\hline $\mathrm{HO}$ & 114 & $21(18 \cdot 4 \%)$ & $93(81 \cdot 6 \%)$ & $18 \cdot 4 \%(11 \cdot 7-26 \cdot 7)$ \\
\hline Nursing Staff & 209 & $81(38 \cdot 8 \%)$ & $128(61 \cdot 2 \%)$ & $38 \cdot 8 \%(32 \cdot 1-45 \cdot 7)$ \\
\hline $\begin{array}{c}\text { Paramedical } \\
\text { Staff }\end{array}$ & 157 & $66(42 \cdot 0 \%)$ & $91(58 \cdot 0 \%)$ & $42 \cdot 0 \%(34 \cdot 2-50 \cdot 1)$ \\
\hline Ward Staff & 88 & $35(39 \cdot 8 \%)$ & $53(60 \cdot 2 \%)$ & $39 \cdot 8 \%(29 \cdot 4-50 \cdot 7)$ \\
\hline Lab Tec & 32 & $16(50 \cdot 0 \%)$ & $16(50 \cdot 0 \%)$ & $50 \cdot 0 \%(31 \cdot 8-68 \cdot 1)$ \\
\hline Other & 76 & $27(35 \cdot 5 \%)$ & $49(64 \cdot 5 \%)$ & $35 \cdot 5 \%(24 \cdot 8-47 \cdot 3)$ \\
\hline \multicolumn{5}{|l|}{ Symptom } \\
\hline Symptomatic & 457 & $145(31 \cdot 7 \%)$ & $312(68 \cdot 3 \%)$ & $31 \cdot 7 \%(27 \cdot 4-36 \cdot 2)$ \\
\hline Asymptomatic & 554 & $165(29 \cdot 8 \%)$ & $389(70 \cdot 2 \%)$ & $29 \cdot 8 \%(26 \cdot 0-33 \cdot 7)$ \\
\hline
\end{tabular}


medRxiv preprint doi: https://doi.org/10.1101/2020.09.29.20203125; this version posted September 30, 2020. The copyright holder for this preprint (which was not certified by peer review) is the author/funder, who has granted medRxiv a license to display the preprint in perpetuity.

It is made available under a CC-BY-NC-ND 4.0 International license .

Table: 2: Univariable and Multivariable analysis of factors associated with seropositivity.

\begin{tabular}{|c|c|c|c|c|c|c|}
\hline & \multicolumn{3}{|c|}{ Univariable Analysis } & \multicolumn{3}{|c|}{ Multivariable Analysis } \\
\hline & OR & $95 \% \mathrm{CI}$ & $\mathrm{P}$ value & OR & $95 \% \mathrm{CI}$ & $P$ value \\
\hline Age & $1 \cdot 00$ & $0 \cdot 99-1 \cdot 01$ & 0.66 & $1 \cdot 00$ & $0 \cdot 99-1 \cdot 01$ & $0 \cdot 71$ \\
\hline Gender & $1 \cdot 19$ & $0 \cdot 89-1 \cdot 59$ & $0 \cdot 24$ & $1 \cdot 02$ & $0 \cdot 89-1 \cdot 41$ & $0 \cdot 21$ \\
\hline \multicolumn{7}{|l|}{ Professional Category } \\
\hline Consultant & $0 \cdot 44$ & $0 \cdot 29-0 \cdot 62$ & $0.00 *$ & $0 \cdot 38$ & $0 \cdot 15-0 \cdot 97$ & $0 \cdot 04 *$ \\
\hline MOs/TMOs & $0 \cdot 49$ & $0 \cdot 33-0 \cdot 73$ & $0 \cdot 00^{*}$ & $0 \cdot 42$ & $0 \cdot 17-1 \cdot 04$ & 0.06 \\
\hline HOs & $0 \cdot 47$ & $0 \cdot 29-0 \cdot 77$ & $0.03 *$ & $0 \cdot 40$ & $1 \cdot 21-4 \cdot 04$ & $0 \cdot 67$ \\
\hline Nursing Staff & $1 \cdot 58$ & $1 \cdot 15-2 \cdot 17$ & $0.05^{*}$ & $1 \cdot 20$ & $1 \cdot 17-4 \cdot 65$ & 0.68 \\
\hline Paramedical Staff & $1 \cdot 79$ & $1 \cdot 26-2 \cdot 53$ & $0 \cdot 01 *$ & $1 \cdot 12$ & $0 \cdot 43-1 \cdot 37$ & $0 \cdot 78$ \\
\hline Ward Staff & $1 \cdot 49$ & $0 \cdot 95-2 \cdot 33$ & 0.78 & $1 \cdot 10$ & $0 \cdot 44-1 \cdot 39$ & $0 \cdot 82$ \\
\hline Lab Technician & $2 \cdot 26$ & $1 \cdot 27-4 \cdot 04$ & $0 \cdot 05^{*}$ & $1 \cdot 49$ & $0 \cdot 43-1 \cdot 55$ & $0 \cdot 32$ \\
\hline Other & $0 \cdot 55$ & $0 \cdot 23-1 \cdot 27$ & $0 \cdot 16$ & $1 \cdot 08$ & $0 \cdot 24-1 \cdot 33$ & $0 \cdot 85$ \\
\hline \multicolumn{7}{|l|}{ Exposure Risk } \\
\hline $\begin{array}{l}\text { Observe social } \\
\text { distancing }\end{array}$ & $1 \cdot 0$ & $0 \cdot 73-1 \cdot 46$ & $0 \cdot 82$ & $1 \cdot 0$ & $0 \cdot 70-1 \cdot 53$ & $0 \cdot 83$ \\
\hline Using face mask & $0 \cdot 69$ & $0 \cdot 51-0 \cdot 93$ & 0.01 & $0 \cdot 67$ & $0 \cdot 49-0.92$ & $0 \cdot 01 *$ \\
\hline Travel abroad & $0 \cdot 70$ & $0 \cdot 50-0 \cdot 98$ & 0.03 & $0 \cdot 73$ & $0 \cdot 52-1 \cdot 04$ & 0.08 \\
\hline $\begin{array}{l}\text { Social distancing with- } \\
\text { in Family }\end{array}$ & $1 \cdot 29$ & $0 \cdot 99-1 \cdot 69$ & $0 \cdot 05$ & $0 \cdot 73$ & $0.55-0.98$ & $0 \cdot 04 *$ \\
\hline Wedding & $0 \cdot 85$ & $0 \cdot 37-1 \cdot 95$ & $0 \cdot 71$ & $1 \cdot 0$ & $0 \cdot 41-2 \cdot 45$ & 0.98 \\
\hline Social Gathering & $0 \cdot 81$ & $0 \cdot 38-1 \cdot 67$ & $0 \cdot 55$ & 0.93 & $0 \cdot 41-2 \cdot 12$ & $0 \cdot 87$ \\
\hline Funeral & $1 \cdot 78$ & $1 \cdot 07-2 \cdot 96$ & $0 \cdot 02$ & $1 \cdot 83$ & $1 \cdot 05-3 \cdot 16$ & $0.03 *$ \\
\hline $\begin{array}{l}\text { School/madrassa } \\
\text { attending }\end{array}$ & $1 \cdot 13$ & $0 \cdot 10-12 \cdot 5$ & 0.92 & 0.94 & $0 \cdot 80-11 \cdot 2$ & $0 \cdot 96$ \\
\hline Local Markets & $1 \cdot 55$ & $1 \cdot 15-2 \cdot 08$ & $0 \cdot 00$ & $1 \cdot 66$ & $1 \cdot 16-2 \cdot 37$ & $0 \cdot 00 *$ \\
\hline Shopping malls & $0 \cdot 75$ & $0 \cdot 43-1 \cdot 30$ & $0 \cdot 31$ & $1 \cdot 0$ & $0 \cdot 54-1 \cdot 88$ & 0.96 \\
\hline Masjid & $0 \cdot 55$ & $0 \cdot 37-0 \cdot 80$ & $0 \cdot 00$ & $0 \cdot 52$ & $0 \cdot 34-0.79$ & $0.001 *$ \\
\hline $\begin{array}{l}\text { Direct contact with } \\
\text { COVID patient }\end{array}$ & $0 \cdot 72$ & $0.54-0 \cdot 94$ & $0 \cdot 01$ & $0 \cdot 83$ & $0 \cdot 62-1 \cdot 11$ & $0 \cdot 22$ \\
\hline $\begin{array}{l}\text { Contact with COVID } \\
\text { patient outside hospital }\end{array}$ & $1 \cdot 0$ & $0 \cdot 78-1 \cdot 66$ & $0 \cdot 72$ & $1 \cdot 0$ & $0.63-1.53$ & $0 \cdot 87$ \\
\hline \multicolumn{7}{|l|}{ Symptoms } \\
\hline Fever & $2 \cdot 14$ & $1 \cdot 54-2 \cdot 97$ & 0.00 & $2 \cdot 36$ & $1 \cdot 52-3 \cdot 68$ & $0 \cdot 00^{*}$ \\
\hline Cough & $1 \cdot 72$ & $1 \cdot 23-2 \cdot 41$ & $0 \cdot 00$ & $1 \cdot 44$ & $0 \cdot 93-2 \cdot 24$ & $0 \cdot 10$ \\
\hline Sneezing & $0 \cdot 17$ & $0 \cdot 51-1 \cdot 12$ & $0 \cdot 17$ & $0 \cdot 56$ & $0 \cdot 63-1 \cdot 12$ & $0 \cdot 10$ \\
\hline Sore Throat & $0 \cdot 79$ & $0 \cdot 57-1 \cdot 10$ & $0 \cdot 17$ & $0 \cdot 78$ & $0 \cdot 57-1 \cdot 11$ & $0 \cdot 16$ \\
\hline Breathlessness & $2 \cdot 13$ & $0 \cdot 96-4 \cdot 72$ & 0.06 & $1 \cdot 31$ & $0 \cdot 52-3 \cdot 25$ & $0 \cdot 56$ \\
\hline Body Aches & $1 \cdot 0$ & $0 \cdot 79-1 \cdot 50$ & $0 \cdot 58$ & $0 \cdot 80$ & $0 \cdot 53-1 \cdot 19$ & $0 \cdot 27$ \\
\hline Diarrhea & $1 \cdot 39$ & $0 \cdot 89-2 \cdot 17$ & $0 \cdot 14$ & $1 \cdot 26$ & $0 \cdot 72-2 \cdot 20$ & $0 \cdot 40$ \\
\hline Loss of taste & $2 \cdot 40$ & $1 \cdot 44-4 \cdot 00$ & $0 \cdot 00$ & $1 \cdot 24$ & $0 \cdot 62-2 \cdot 50$ & $0 \cdot 53$ \\
\hline Loss of smell & $3 \cdot 80$ & $2 \cdot 18-6 \cdot 61$ & $0 \cdot 00$ & $2 \cdot 95$ & $1 \cdot 46-5 \cdot 98$ & $0 \cdot 00 *$ \\
\hline Pain Abdomen & $0 \cdot 72$ & $0 \cdot 39-1 \cdot 34$ & $0 \cdot 30$ & $0 \cdot 56$ & $0 \cdot 27-1 \cdot 16$ & $0 \cdot 12$ \\
\hline Severe headache & $1 \cdot 0$ & $0 \cdot 64-1 \cdot 59$ & 0.95 & $0 \cdot 77$ & $0 \cdot 44-1 \cdot 38$ & $0 \cdot 39$ \\
\hline
\end{tabular}


medRxiv preprint doi: https://doi.org/10.1101/2020.09.29.20203125; this version posted September 30, 2020. The copyright holder for this preprint (which was not certified by peer review) is the author/funder, who has granted medRxiv a license to display the preprint in perpetuity.

\section{Graph 1:}

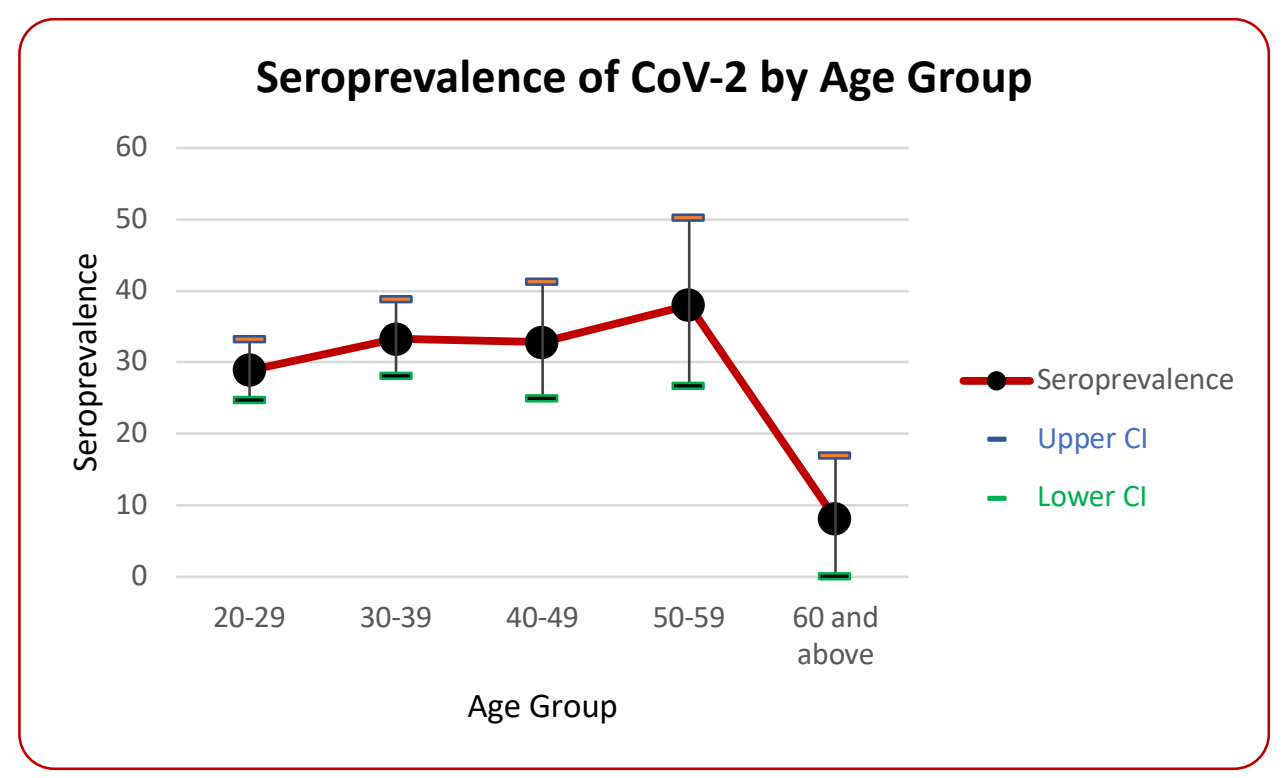

\section{Graph 2:}

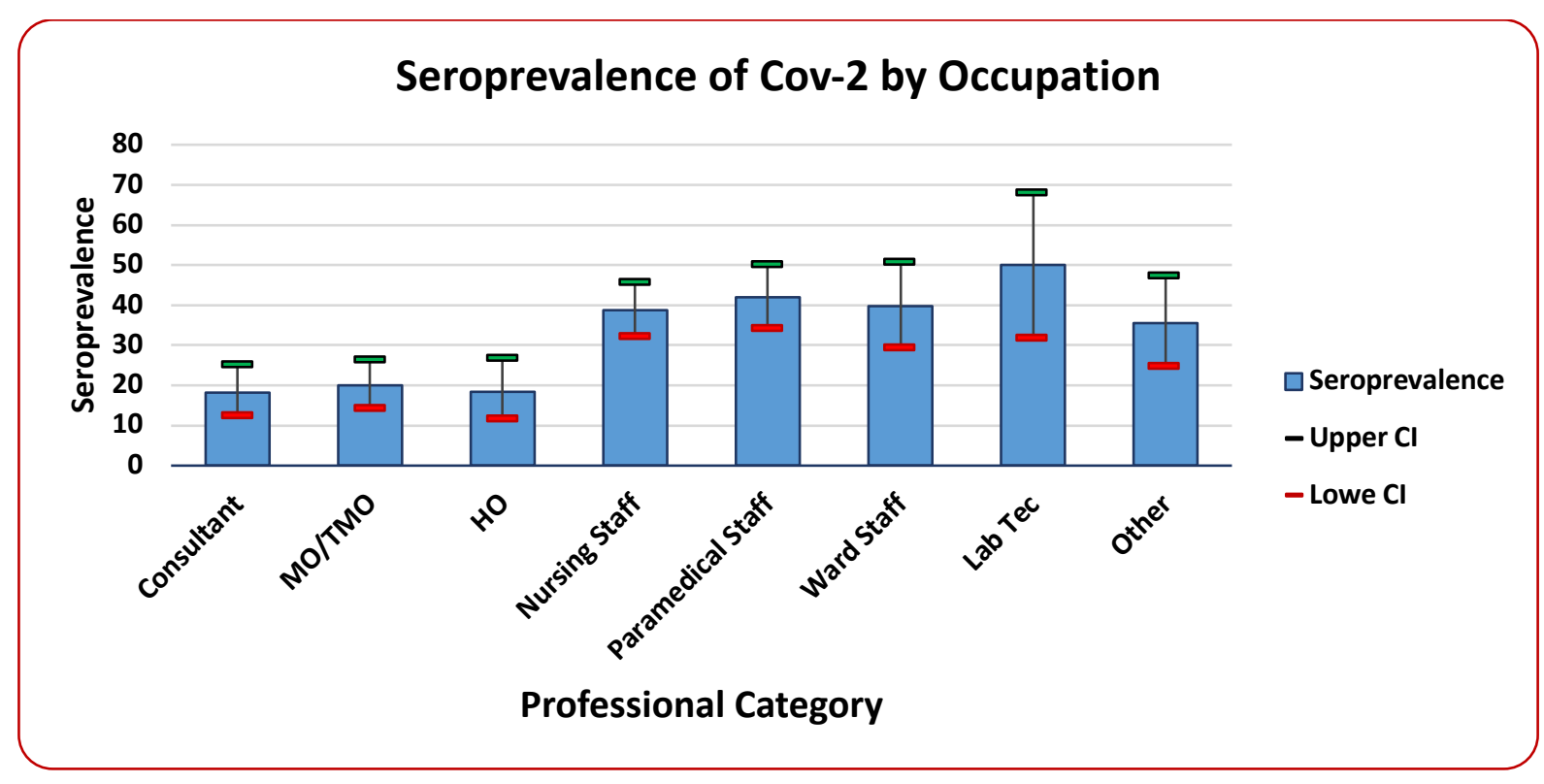




\section{References:}

1. Mahase E. Covid-19: First coronavirus was described in The BMJ in 1965. BMJ. 2020: 1547.

2. Tsang K, Ho P, Ooi G, et al. A Cluster of Cases of Severe Acute Respiratory Syndrome in Hong Kong. New England Journal of Medicine. 2003; 348(20):1977-1985.

3. Haagmans B, Al Dhahiry S, Reusken C, Raj V, Galiano M, Myers R et al. Middle East respiratory syndrome coronavirus in dromedary camels: an outbreak investigation. The Lancet Infectious Diseases. 2014;14(2):140-145.

4. Fehr AR, and Perlman S. Corona viruses: an overview of their replication and pathogenesis, in Corona viruses. Springer. 2015;1282:1-23.

5. Advice on the use of point-of-care immunodiagnostic tests for COVID-19 https://www.who.int/news-room/commentaries/detail/advice-on-the-use-of-point-of-careimmunodiagnostic-tests-for-covid-19. Accessed June 24, 2020.

6. Zhao J, Yuan Q, Wang H, Liu W, Liao X, Su Y et al. Antibody Responses to SARS-CoV-2 in Patients of Novel Coronavirus Disease 2019. Clinical infectious diseases. 2020;344

7. Deeks J, Dinnes J, Takwoingi Y, Davenport C, Spijker R, Taylor-Phillips S et al. Antibody tests for identification of current and past infection with SARS-CoV-2. Cochrane Database of Systematic Reviews. 2020;6:13652

8. Long, Q, Liu B, Deng H. et al. Antibody responses to SARS-CoV-2 in patients with COVID19. Nat Med. 2020;26: $845-848$

9. Burki T. K. Testing for COVID-19. The Lancet. Respiratory medicine. 2020;8(7):63-64.

10. Roche's COVID-19 antibody test receives FDA Emergency Use Authorization and is available in markets accepting the CE mark. http://www.roche.com/media/releases/med-cor2020-05-03.html. Accessed June 30, 2020.

11. Baraniuk C. Covid-19 antibody tests: a briefing; The BMJ. 2020;369:2284.

12. Chen Y, Tong X, Wang J, Huang W, Yin S, Huang R et al. High SARS-CoV-2 antibody prevalence among healthcare workers exposed to COVID-19 patients. Journal of Infection. 2020;81(3):420-426.

13. Catherine FH, Nina V, Thomas B, Dan L et al.Pandemic Peak SARS-CoV-2 infection and seroconversion rates in London frontline health care workers. The Lancet. 2020;396(10246): 6-7 
14. Garcia-Basteiro A, Moncunill G, Tortajada M, Vidal M, Guinovart C, Jiménez A et al. Seroprevalence of antibodies against SARS-CoV-2 among health care workers in a large Spanish reference hospital. Nature Communications. 2020;11(1).

15. Antibodies against SARS-CoV-2 among health care workers in a country with low burden of COVID-19.https://www.medrxiv.org/content/10.1101/2020.06.23.20137620v1. Accessed June 27, 2020.

16. Chu D, Akl E, Duda S, Solo K, Yaacoub S, Schünemann H et al. Physical distancing, face masks, and eye protection to prevent person-to-person transmission of SARS-CoV-2 and COVID-19: a systematic review and meta-analysis. The Lancet. 2020;395(10242):19731987.

17. Resident physician exposure to novel coronavirus (2019-nCoV, SARS-CoV-2) within New York City during exponential phase of COVID-19pandemic: Report of the New York City Residency Program Directors COVID-19 Research Group. https://www.medrxiv.org/content/10.1101/2020.04.23.20074310v1. Accessed June 28, 2020.

18. President Alvi outlines plan agreed with ulema on congregational prayers during Ramzan. https://www.dawn.com/news/1550265. Accessed June 29, 2020.

19. Steensels D, Oris E, Coninx L, Nuyens D, Delforge M, Vermeersch P, Heylen, L. HospitalWide SARS-CoV-2 Antibody Screening in 3056 Staff in a Tertiary Center in Belgium. JAMA. 2020;324(2):195.

20. Long Q, Tang X, Shi Q, Li Q, Deng H, Yuan J et al. Clinical and immunological assessment of asymptomatic SARS-CoV-2 infections. Nature Medicine. 2020;26(8):1200-1204.

21. Stubblefield W, Talbot H, Feldstein L, Tenforde M, Rasheed M, Mills L et al. Seroprevalence of SARS-CoV-2 Among Frontline Healthcare Personnel During the First Month of Caring for Patients with COVID-19-Nashville, Tennessee. Clinical Infectious Diseases. 2020;

22. Davies N, Klepac P, Liu Y, Prem K, Jit M, Eggo R. Age-dependent effects in the transmission and control of COVID-19 epidemics. Nature Medicine. 2020;26(8):1205-1211.

23. Ip Margarat, Chan P, Lee N, Wu A, Ng T, Chan L. Seroprevalence of Antibody to Severe Acute Respiratory Syndrome (SARS)-Associated Coronavirus among Health Care Workers in SARS and Non-SARS Medical Wards. Clinical Infectious Diseases. 2004;38(12):e116e118. 
medRxiv preprint doi: https://doi.org/10.1101/2020.09.29.20203125; this version posted September 30, 2020. The copyright holder for this preprint (which was not certified by peer review) is the author/funder, who has granted medRxiv a license to display the preprint in perpetuity.

It is made available under a CC-BY-NC-ND 4.0 International license .

24. Fei Z, Ting Y, Ronghui D et al; Clinical Course and Risk factors for mortality of adults in patients with COVID-19 in Wuhan, China: a retrospective study: Lancet 2020;385:1054- 63 